\title{
HER2/neu protein expression and fine needle breast aspiration from Argentinean patients with non-palpable breast lesions
}

\author{
WENDY GABRIELA DOMÍNGUEZ ${ }^{1,6}$, HÉCTOR NARDI $^{2}$, HÉCTOR MONTERO $^{3}$, \\ ESTEBAN VINCENT ${ }^{4}$, MARÍA MARTA CORTE ${ }^{5}$ and GABRIELA ANDREA BALOGH ${ }^{6}$ \\ ${ }^{1}$ Department of Biochemistry and Genetics, Texas A\&M University, College Station, TX, USA; \\ ${ }^{2}$ Departamento de Ginecología, Hospital Interzonal Dr. Jose Penna; ${ }^{3}$ Departamento de Ginecología, Hospital Español; \\ ${ }^{4}$ Departamento de Ginecología, Hospital de la Asociación Médica de Bahía Blanca; ${ }^{5}$ Laboratorio de Patología; \\ ${ }^{6}$ CERZOS-CONICET, Centro Científico Tecnológico Bahía Blanca, Bahía Blanca, Argentina
}

Received March 9, 2010; Accepted May 12, 2010

DOI: 10.3892/etm_00000094

\begin{abstract}
The objective of this pilot project was to investigate whether the breast fine needle aspiration (FNA) technique is a useful tool for determining the increased risk of breast cancer in patients with non-palpable breast lesions. FNA is a minimally invasive technique that isolates mammary epithelial cells from breast cells in the suspicious region. In this study, two FNA samples were collected from 12 patients. The level of HER2/ neu expression at the mRNA level (in serum) was measured in each patient. As gene amplification is characteristic of cancer cells and may assist in diagnosis and prognostic assessment, it is crucial that gene amplification of HER2/neu in patients with nonpalpable breast lesions is compared to breast biopsy results. In serum, the level of HER2/neu was determined by ELISA assay. Gene amplification was determined by PCR and confirmed by IHC employing monoclonal ERRB2 in the FNA sample. The results indicate that FNA has a good correlation with breast biopsy. FNA combined with mammographic imaging is a strong tool for determining favorable treatment options for patients.
\end{abstract}

\section{Introduction}

Breast cancer is believed to be the result of progressive molecular and morphological changes that develop in ductal epithelial cells. These changes have been studied extensively. Current detection methods can only identify in situ or invasive diseases. We know that the vast majority, if not all, of these cancers have a pre-cancerous phase. Newer methodologies are evolving to shift this treatment paradigm to predict which women are at the highest risk of developing breast cancer and to prevent the development of cancerous lesions.

Correspondence to: Dr Gabriela A. Balogh, CONICET, CERZOS, Centro Científico Tecnológico Bahia Blanca, Camino La Carrindanga Km 7, Bahía Blanca, Argentina

Email: gbalogh@criba.edu.ar

Key words: non-palpable breast carcinoma, HER2/neu, gene expression, breast fine needle aspiration
Widespread screening with mammography and physical breast examination have been shown to reduce breast cancer mortality. However, many examinations are false-positive, with positive predictive values for non-palpable and palpable lesions ranging from $15-38 \%$ (1-3). Prior to the advent of percutaneous biopsy methods, many women underwent open surgical biopsy. With the introduction of the percutaneous sampling of non-palpable lesions, fine needle aspiration (FNA) biopsy and core-needle biopsy have been used more widely in the evaluation of non-palpable breast lesions (4-6).

Wrensch et al (7) analyzed nipple aspirate fluid collected from more than 2,700 women. This study, which had an average follow-up of 12.7 years, demonstrated that women with cellular atypia had a relative risk of developing breast cancer that was 4.9 times greater than that of women who did not have atypical cells. The $95 \%$ confidence interval for this finding was 1.7-13.9.

Women with a first-degree family history of breast cancer in addition to atypical cells had an 18-fold increased relative risk; however, the extremely wide confidence interval of 4.6-70.2, determined with a small number of subjects, casts some doubt on the strength of this association. The presence of atypia confers an increased risk for the development of breast cancer. Wrensch et al confirmed these findings in a follow-up study published in 2001 (8). Fabian et al (9), using ductal epithelial cells collected with random periareolar fineneedle aspiration from 480 high-risk women, demonstrated similar results. This study, which had a median follow-up of 45 months, found that high-risk women with atypical cells had a relative risk of developing breast cancer that was 5 times greater than high-risk women without atypical cells. The $95 \%$ confidence interval ranged from 2.0 to 12.6.

Until a cure is found, the early detection of breast cancer is imperative. Improved methods to detect and diagnose breast cancer early, when it is most curable, are required if a significant impact on breast cancer-related morbidity and mortality is to be made. Over $95 \%$ of breast cancers begin in the cells lining the breast ducts (10). It can take up to 8-10 years before these cells grow into a tumor large enough to be detected by mammography. Two innovative technolo- 




Figure 1. General schema of the procedures employed in this study. From each patient two sample types were collected: a peripheral blood sample and a breast fine needle aspirate (FNA) from the non-palpable lesions. The blood sample was separated into two samples: one to isolate DNA and the other to obtain serum. The total DNA samples were employed to analyze HER2/neu mRNA expression by PCR, and the serum samples were utilized to quantify HER2/neu protein levels using ELISA assay. The FNA samples were analyzed by a cytopathologist to observe the quality of the FNA sample (number of cells) and to study the type of epithelial cells present in the sample. The acellular FNA samples were inadequate for analysis.

gies to monitor for atypical ductal epithelial cells are ductal lavage (DL) (11) and nipple aspirate fluid (NAF) (12), which, in conjunction with the detection of novel biomarkers linked to breast cancer, are being investigated for use in the early detection and diagnosis of breast cancer. However, DL or NAF cytology alone is not sufficiently sensitive to identify the subgroup of women who are on a progressive pathway leading to breast cancer (13).

Gene amplification is a characteristic feature of cancer cells that results in increased production of specific proteins required for the acquisition and maintenance of the malignant phenotype. Amplification of certain oncogenes plays an important role in the progression of many types of tumors (14-16). For example, the MYCN oncogene is amplified in neuroblastomas, MYC and MYCL are amplified in small-cell lung cancer, and HER2/neu is amplified in breast and ovarian cancers. Detection of such amplifications may, in some instances, assist in diagnosis and in prognostic assessment. Gene amplification also contributes to the development of resistance to cytotoxic drugs. V-Erb-B2 erythroblastic leukemia viral oncogene homolog 2 or the HER2/NEU (Her-2/neu) oncogene, which codes for a $185-\mathrm{kDa}$ transmembrane growth factor receptor, is amplified and/or overexpressed in $15-35 \%$ of breast carcinomas (17-20). The association of HER2/neu amplification and overexpression with rapid proliferation, low estrogen receptor content and high-grade ductal carcinomas suggests that this oncogene plays an important role in the progression of breast cancer. The preoperative detection of HER2/neu amplification in non-palpable breast lesion patients using FNA may be of particular relevance and could be useful clinically.

Our objective in this study was to compare the level of HER2/neu gene amplification in patients with non-palpable breast lesions with the presence or absence of atypical cells in their breast cells obtained by employing FNA.

The amplification of the HER2/neu gene is more frequent in carcinoma in situ than in invasive types (21). Detection of HER2/neu by a PCR-based method may aid in the diagnosis of non-palpable breast lesions in women with unclear or dense mammography images. Since this gene amplification is related to high proliferation, it may provide useful preoperative information regarding certain types of intraductal carcinoma, and may also predict the response to chemotherapy.

\section{Materials and methods}

Breast samples. Twelve patients were enrolled in this pilot project: 9 patients with a non-palpable breast lesion and 3 healthy control women without breast cancer. FNA was used to obtain a breast specimen in the non-palpable breast lesion patients and healthy control women. A written consent form was signed by each patient prior to the sampling. A general schema of the procedures carried out in this study is shown in Fig. 1.

Fine needle aspiration technique. The FNAs were performed by a gynecologist in a preoperative room. In this technique, a thin $21-\mathrm{G}$ needle with a $10-\mathrm{ml}$ syringe was inserted into the breast, and the cells were aspirated. In non-palpable breast lesion patients, a blind sample from suspicious breast tissue was isolated. The extracted cells were used to make two smears on slides which were stained with PAP stain and examined under an optical microscope. FNA is a safe and minor surgical procedure and less traumatic than an open surgical biopsy. Significant complications are usually rare and depend on the body site. The skin above the insertion area was swabbed with an antiseptic solution and draped with sterile surgical towels. In the normal healthy control women, the FNA procedure was performed in both breasts (two each).

Blood serum sample. A peripheral blood sample $(10 \mathrm{ml})$ was taken from each patient after FNA. The serum was isolated and maintained at $-20^{\circ} \mathrm{C}$ until the HER2/neu gene expression ELISA assay was performed for all of the patient samples. 
Table I. Cytopathology report from breast fine needle aspirate samples.

\begin{tabular}{|c|c|c|c|c|c|c|}
\hline $\begin{array}{l}\text { Patient } \\
\text { no. }\end{array}$ & ID no. & $\begin{array}{c}\text { Age } \\
\text { (years) }\end{array}$ & $\begin{array}{l}\text { Family } \\
\text { history }\end{array}$ & $\begin{array}{l}\text { Clinical } \\
\text { diagnosis }\end{array}$ & Breast FNA sample & $\begin{array}{c}\text { Cytopathology } \\
\text { report }\end{array}$ \\
\hline 1 & 806200351 & 65 & No & $\begin{array}{l}\text { Non-palpable } \\
\text { breast carcinoma }\end{array}$ & $\begin{array}{l}\text { Good cellularity } \\
\text { with blood }\end{array}$ & Malignant cells \\
\hline 2 & 806200279 & 37 & No & $\begin{array}{l}\text { Non-palpable } \\
\text { breast carcinoma }\end{array}$ & Few epithelial cells & Cellular atipia \\
\hline 3 & 807010752 & 72 & Yes & $\begin{array}{l}\text { Non-palpable } \\
\text { breast carcinoma }\end{array}$ & Few epithelial cells & Cellular atipia \\
\hline 4 & 807101541 & 49 & Yes & $\begin{array}{l}\text { Non-palpable } \\
\text { breast carcinoma }\end{array}$ & Good cellularity & $\begin{array}{l}\text { Benign breast } \\
\text { epithelial cells }\end{array}$ \\
\hline 5 & 807280700 & 30 & Yes & $\begin{array}{l}\text { Non-palpable } \\
\text { breast carcinoma }\end{array}$ & Good cellularity & $\begin{array}{l}\text { Benign breast } \\
\text { epithelial cells }\end{array}$ \\
\hline 6 & 807021404 & 64 & Yes & $\begin{array}{l}\text { Non-palpable } \\
\text { breast carcinoma }\end{array}$ & $\mathrm{n} / \mathrm{p}$ & $\mathrm{n} / \mathrm{p}$ \\
\hline 7 & 808062023 & 50 & Yes & $\begin{array}{l}\text { Non-palpable } \\
\text { breast carcinoma }\end{array}$ & Acellular material & Acellular material \\
\hline 8 & 8101510882 & 58 & No & $\begin{array}{l}\text { Non-palpable } \\
\text { breast carcinoma }\end{array}$ & Acellular material & Acellular material \\
\hline 9 & 8101510878 & 62 & No & $\begin{array}{l}\text { Non-palpable } \\
\text { breast carcinoma }\end{array}$ & $\begin{array}{l}\text { Good cellularity } \\
\text { with blood }\end{array}$ & $\begin{array}{l}\text { Benign breast } \\
\text { epithelial cells }\end{array}$ \\
\hline 10 & 8103102312 & 28 & No & Control patient & Acellular material & Acellular material \\
\hline 11 & 810290262 & 39 & Yes & Control patient & Acellular material & Acellular material \\
\hline 12 & 811042114 & 60 & Yes & Control patient & Few epithelial cells & $\begin{array}{l}\text { Benign breast } \\
\text { epithelial cells }\end{array}$ \\
\hline
\end{tabular}

The FNA cytopathologic reports and FNA quality for all patients involved in this study are included. Patient ID, age (years) and clinical diagnoses are also indicated. Good cellularity, $>100$ epithelial cells; few epithelial cells, between 20 and 50 cells; acellular material, <20 cells in the FNA sample. $n / p$, not performed.

DNA isolation from breast samples. Genomic DNA was isolated from the blood samples using Nexttec ${ }^{\mathrm{TM}}$ Clean Columns (Nexttect Inc., Leverkusen, Germany). As opposed to other protocols, no DNA was retained by the column resin. Instead, proteins, detergents and low-molecular-weight compounds were retained. The DNA was passed through the column during a short, one-step purification procedure.

Amplification of the HER2/neu gene by PCR-based method. Genomic DNA (100 ng) was amplified for the HER2/neu gene by PCR methodology using Taq DNA polymerase (Promega) followed by the thermocycling program: after denaturalization at $95^{\circ} \mathrm{C}$ for $2 \mathrm{~min}, 35$ cycles of denaturalization at $95^{\circ} \mathrm{C}$ for $30 \mathrm{sec}$, annealing at optimal primer temperature for $30 \mathrm{sec}$, an extension cycle at $72^{\circ} \mathrm{C}$ for $30 \mathrm{sec}$ and a final extension at $72^{\circ} \mathrm{C}$ for $10 \mathrm{~min}$ were performed. The PCR reaction was performed with a specific primer sequence that codifies for the HER $2 /$ neu gene. A parallel PCR reaction was also performed to amplify $\beta$-actin as a control gene amplification.
HER2/neu ELISA assay. The HER2/neu ELISA kit is a sandwich-type enzyme immunoassay that utilizes two monoclonal antibodies directed to the extracellular domain (ECD) of HER2/neu. The assay quantifies either the full-length molecule in tumor tissue (p185) or the ECD (p105) in serum, plasma, cell cultures and fluids. The capture antibody was immobilized on the interior surface of the microplate wells. To perform the assay, an appropriate volume of specimen was incubated in the coated wells to allow binding of the antigen by the capture antibody. The immobilized antigen was reacted with the detector antiserum. The amount of detector antibody bound to the antigen was measured using a colored reaction product that was quantitated by spectrophotometry reflecting the amount of protein in the sample.

\section{Results}

Breast fine needle aspiration cytology. Our main objective in this pilot study was to determine whether breast FNA is feasible and accurate compared to breast biopsy in patients 

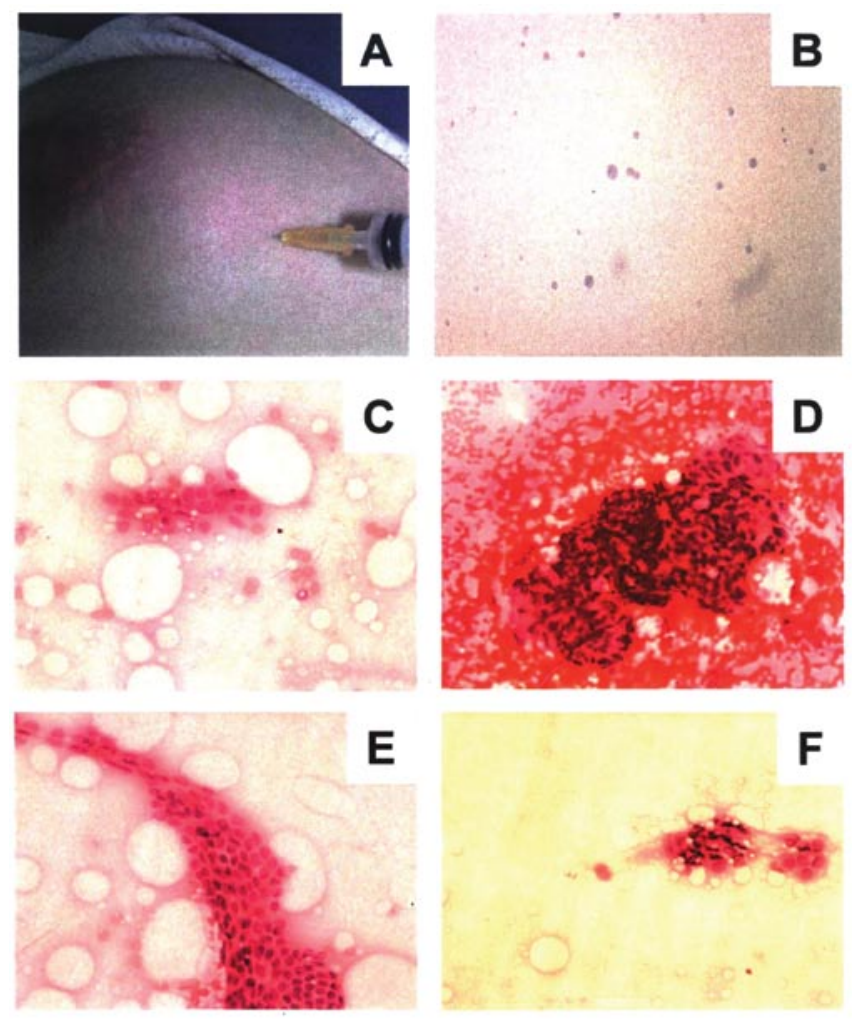

Figure 2. (A) Representative image of the breast fine needle aspiration samples from a normal patient. (B-F) Microphotography of breast FNA samples. The FNA samples were isolated by a gynecologist. After the samples were collected, the slides with the material were used immediately and maintained in alcohol (70\%) until they were transported to the cytopathology laboratory Each slide with an FNA sample was stained and analyzed under an optical microscope at $\times 20$ and $\times 40$. (B) Acellular material, (C) benign breast cells from a healthy control woman, (D) malignant or tumoral breast cells, (E) FNA sample with benign breast epithelial cells and (F) cellular atipia.

with non-palpable breast lesions. Nine non-palpable breast lesion patients (30-72 years of age) and 3 healthy control patients (28-60 years of age) were studied. FNA was performed in 12 patients: 9 with non-palpable breast lesions and 3 healthy control women. The efficiency of FNA is documented in Table I. The FNA results revealed that 2/9 nonpalpable breast lesion patients had acellular material in their FNA samples, in 1/9 patients FNA was not performed, and in $6 / 9$ patients cellular material was obtained (66.6\%). Among the 6 patients for whom cellular material was obtained, the cytopathology report indicated that $3 / 6$ had benign breast cells (50\%), 2 had cellular atipia (33.3\%) and 1 had malignant breast cells (16.7\%) in their FNAs. Of the 3 healthy control women, only 1 exhibited benign breast epithelial cells in the FNA sample and the remaining patients had acellular material. Fig. 2A shows an image of an FNA sample from a control female subject, and B-F are images from the breast cytology. Fig. 2B is a representative image of an FNA sample with acellular material, and $\mathrm{C}$ shows benign breast cells from a healthy control woman. Fig. 2D shows malignant or tumoral breast cells from a non-palpable breast lesion from patient no. 1, and E shows an FNA sample of benign breast epithelial cells from a non-palpable breast lesion patient. Fig. 2F is a representative image of an FNA sample with cellular or mild atipia.



Figure 3. Levels of HER2/neu protein expression by ELISA assay. HER2/ neu levels measured in $\mathrm{ng} / \mathrm{ml}$ in serum samples by ELISA assay employing automatic equipment system. Six out of 9 patients were analyzed, and negative and positive samples were also used as controls.

HER2/neu protein expression in serum samples. The levels of HER2/neu protein expression in serum from patient nos. $1,2,4,5$ and 6 with non-palpable breast lesions are shown in Fig. 3. One healthy control woman was included as a negative control, and one invasive $\left(\mathrm{HER} 2^{+}\right)$breast carcinoma patient as positive control. The levels of HER2 protein expression in serum were low in all of the patients with non-palpable breast lesions, which were considered HER2-. The serum samples were analyzed from some of the available patients included in this study.

HER2/neu gene expression in blood samples. HER2/neu gene amplification of the control DNA sample from a healthy control woman as a control of gene expression employing the housekeeping gene $\beta$-actin is shown in Fig. 4A. The molecular weights corresponding to HER $2 /$ neu and $\beta$-actin amplification bands are 198 and $550 \mathrm{bp}$, respectively. The intensity relationship (R) values between HER2/neu and $\beta$-actin amplification bands were employed to semi-quantify the HER2/neu expression level in the remaining patients. HER2/neu and $\beta$-actin gene amplification in patient nos. 1-9 is shown in Fig. 4B. The levels of HER $2 /$ neu expression with respect to $\beta$-actin in all of the patients as well as in the DNA control, are represented in Fig. 5A. The value of R (HER $2 /$ neu/ $\beta$-actin) was considered to be 1.0 in the DNA control. Fig. $5 \mathrm{~B}$ shows the $\mathrm{R}$ values of all of the patients. As shown in Fig. 5B, patient nos. 1, 4, 8 and 9 had a $>1.5$-fold increase in HER2/neu gene expression with respect to the control. However, patient nos. 2, 5 and 7 had a $>2$.0-fold lower HER2/neu gene expression with respect to the control. Patient nos. 3 and 6 demonstrated HER2/neu gene expression at the same level when compared to the control DNA.

\section{Discussion}

Mammography is generally accepted as a useful diagnostic clinical tool for characterizing known breast lesions so that appropriate and timely treatment can be administered. However, it remains grossly underutilized at what it does best: screening. Breast FNA is a minimally invasive procedure that allows the collection of representative breast epithelial cells for diagnosis and is reliable in the assessment of prognostic and predictive markers in breast cancer. The sensitivity of 
A

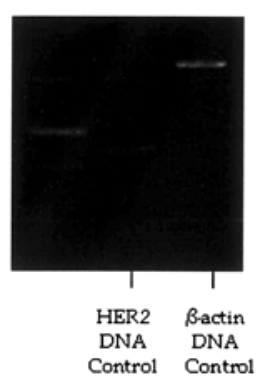

B

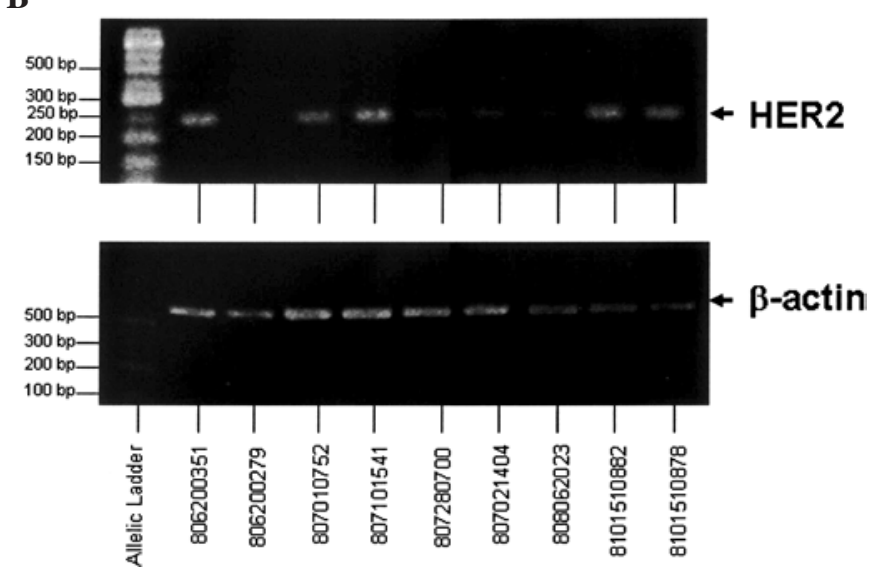

Figure 4. HER2/neu mRNA expression by PCR analysis. (A) A HER2/neu PCR product of control DNA from a normal control woman. $\beta$-actin was also amplified to normalize the HER2/neu expression in each sample. (B) The HER2/neu PCR products in the 9 patients with non-palpable breast lesions. $\beta$-actin was used as a control.

A



B

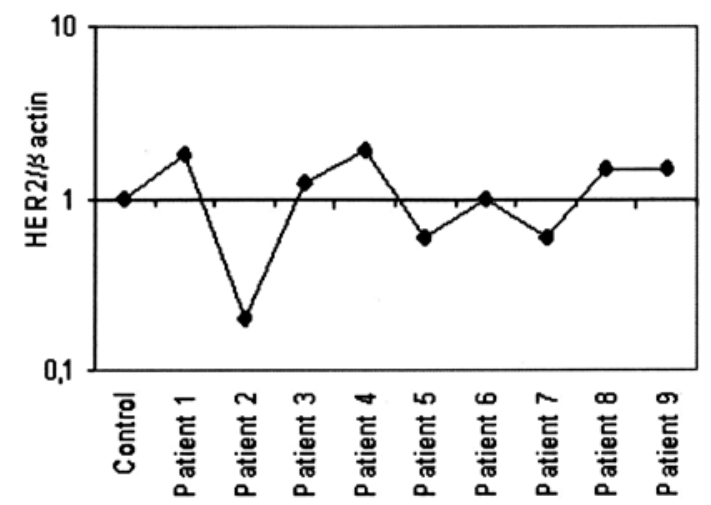

Figure 5. HER2/neu mRNA level expression by PCR assay. The graphical images represent the quantification of the HER2/neu expression level from Fig. 4. The agarose gels were scanned, and each band was quantified to analyze the relative expression with respect to $\beta$-actin. (A) The level of expression in both HER2/neu and $\beta$-actin bands from all patients and (B) the relative expression of HER2/neu at the mRNA level with respect to $\beta$-actin.

mammography in cancer detection needs to be high, but it is also important in order to achieve a high diagnostic specificity to avoid the morbidity associated with unnecessary surgical biopsy. It is in this area that we envision FNA as a useful tool - to determine whether or not to perform surgery on a lesion that is non-palpable and without a clear mammography image. In this study, we demonstrated that FNA has a very good correlation with breast biopsy. The presence of atypical hyperplasia in the breast FNA sample plus a suspicious mammographical image is a powerful tool for defining favorable treatment options for that patient.

Immunohistochemistry (IHC) provides a useful method for defining the type of cancer a patient has and the prognosis. Based on this information, a course of treatment can be determined according to the factors that the cancerous cells may be receptive to. A patient bearing cancer with an overexpression of HER2/neu has a poor prognosis, but is a candidate for treatment with Herceptin. Thus, IHC yields quick results, is cost effective and is easy to perform.
Further investigation is warranted to confirm whether FNA is a suitable method for predicting and analyzing the development of breast cancer. It is crucial that more samples from different patients are collected in order to determine whether there is a correlation between the level of HER2/ neu expression and breast cancer development. Follow-up is also recommended for a determined number of years (at least five) to determine whether the patient develops breast cancer.

These findings provide strong support to a previous study (8), which demonstrated that hyperplasia and atypical hyperplasia diagnosed in nipple aspirates of breast fluid are associated with an increased risk of breast cancer.

\section{Acknowledgements}

We are grateful to Dr Roberto Gentili from IACA Laboratorios, Bahía Blanca, Argentina for his financial support which made this research possible. 


\section{References}

1. Spivey GH, Perry BW, Clark VA, et al: Predicting the risk of cancer at the time of breast biopsy. Variation in the benign to malignant ratio. Am Surg 48: 326-332, 1982.

2. Molloy M, Azarow K, Garcia VF, et al: Enhanced detection of preinvasive breast cancer: combined role of mammography and needle localization biopsy. J Surg Oncol 40: 152-154, 1989.

3. Basset LW, Liu TH, Giuliano AE, et al: The prevalence of carcinoma in palpable vs. impalpable, mammographically detected lesions. AJR Am J Rowntgenol 157: 21-24, 1991.

4. Sickles E: Screening for breast cancer with mammography. Radiology 179: 463-468, 1991.

5. Lidbrink E, Elfving J, Fussell J, et al. Neglected aspects of false positive findings of mammography in breast cancer screening: analysis of false positive cases from the Stockholm trial. BMJ 312: 273-276, 1996.

6. Burrell HC, Pinder SE, Wilson AR, et al: The positive predictive value of mammographic signs: a review of 425 non-palpable breast lesions. Clin Radiol 51: 277-281, 1996.

7. Wrensch MR, Petrakis NL, King EB, et al: Breast cancer incidence in women with abnormal cytology in nipple aspirates of breast fluid. Am J Epidemiol 135: 130-141, 1992.

8. Wrensch MR, Petrakis NL, Miike R, et al: Breast cancer risk in women with abnormal cytology in nipple aspirates of breast fluid. J Natl Cancer Inst 93: 1791-1798, 2001.

9. Fabian CJ, Kimler BF, Zalles CM, et al: Short-term breast cancer prediction by random periareolar fine-needle aspiration cytology and the Gail risk model. J Natl Cancer Inst 92: 1217-1227, 2000.

10. Wright $\mathrm{T}$ and McGechan A: Breast cancer: new technologies for risk assessment and diagnosis. Mol Diagn 7: 49-55, 2003.

11. Dooley WC, Ljung BM, Veronesi U, et al: Ductal lavage for detection of cellular atypia in women at high risk for breast cancer. J Natl Cancer Inst 93: 1624-1632, 2001.

12. Petrakis NL: Nipple aspirate fluid in epidemiologic studies of breast disease. Epidemiol Rev 15: 188-195, 1993.
13. Wrensch M, Petrakis NL, King EB, et al: Breast cancer risk associated with abnormal cytology in nipple aspirates of breast fluid and prior history of breast biopsy. Am J Epidemiol 137: 829-833, 1993.

14. Alitalo K and Schwab M: Oncogene amplification in tumor cells. Adv Cancer Res 47: 235-281, 1986.

15. Schwab M and Amler LC: Amplification of cellular oncogenes: a predictor of clinical outcome in human cancer. Genes Chromosomes Cancer 1: 181-193, 1990.

16 Einarsdóttir K, Rosenberg LU, Humphreys $\mathrm{K}$, et al: Comprehensive analysis of the ATM, CHEK2 and ERBB2 genes in relation to breast tumour characteristics and survival: a population-based case-control and follow-up study. Breast Cancer Res 8: R67, 2006.

17. Choi YH, Ahn JH, Kim SB, et al: Tissue microarray-based study of patients with lymph node-negative breast cancer shows that HER2/neu overexpression is an important predictive marker of poor prognosis. Ann Oncol 20: 1337-1343, 2009.

18. Egervari K, Toth J, Nemes Z, et al: An alternative and reliable real-time quantitative PCR method to determine HER2/neu amplification in breast cancer. Appl Immunohistochem Mol Morphol 17: 247-254, 2009.

19. D'Alessandro C, Dellapasqua S, Orlando L, et al: Role of endocrine responsiveness and HER $2 /$ neu overexpression in inflammatory breast cancer treated with multimodality preoperative therapy. Breast J 14: 435-441, 2008.

20. Dunn L and Demichele A: Genomic predictors of outcome and treatment response in breast cancer. Mol Diagn Ther 13: 73-90, 2009.

21. Motomura K, Koyama H, Noguchi S, et al: Detection of c-erbB-2 gene amplification in nipple discharge by means of polymerase chain reaction. Breast Cancer Res 33: 89-92, 1995. 